\title{
Efficacy and Safety of GLP-1 Agonists in Chronic Kidney Disease: A Case Series
}

\section{Awdishu L and Morello CM*}

Skaggs School of Pharmacy and Pharmaceutical Sciences, University of California, San Diego, USA

*Corresponding author: Candis M. Morello, PharmD, CDE, FCSHP, FASHP, Professor of Clinical Pharmacy and Associate Dean for Student Affairs, Skaggs School of Pharmacy and Pharmaceutical Sciences, University of California, San Diego, 9500 Gilman Dr., La Jolla, CA 92093-0657, USA, Tel: 858-822-5586

\begin{abstract}
Introduction: Tight glycemic control has been demonstrated to reduce the incidence of microvascular complications in type 1 and 2 diabetes. However, tight control comes at a risk of hypoglycemia, which is further increased in advanced diabetic kidney disease. GLP-1 agonists significantly lower $\mathrm{HgA} 1 \mathrm{c}$ and have added benefits of early satiety and weight loss. However, the safety and efficacy of these agents has not been well documented in CKD stage 3-4.
\end{abstract}

Methods: This is a retrospective case series of patients with diabetes and CKD stages 3-4 who were prescribed a GLP-1 agonist. Patient demographics, co-morbidities, vital signs, HgA1c, Scr, eGFR, urine protein to creatinine ratio (UPC) as measured during clinical care were recorded before and after GLP-1 agonist initiation.

Results: A total of 5 patients with diabetes and CKD stage 3-4 were included in this case series. Two patients received exenatide, two liraglutide and one received dulaglutide. Patients were 66.9 years old (47.7-77.6) with the majority being male $(60 \%)$ and caucasian ethnicity $(80 \%)$. The median number of co-morbidities was 8 (5-14) with hypertension, hyperlipidemia and cardiovascular complications most common. The median $\mathrm{HgA} 1 \mathrm{c}$ at initiation of therapy was $8.3 \%(8-10.1)$ and the reduction in $\mathrm{HgA} 1 \mathrm{c}$ was $2.2 \%(0.8-3)$. The median $\mathrm{BMI}$ at initiation of a GLP-1 agonist was $34.3(27.8-36) \mathrm{kg} / \mathrm{m}^{2}$ and the median decrease in BMl over the duration of therapy was 1 $(-0.32-5.7) \mathrm{kg} / \mathrm{m}^{2}$. The eGFR at initiation of therapy was 46 $(29-48) \mathrm{mL} / \mathrm{min} / 1.73 \mathrm{~m}^{2}$ and remained relatively stable over the duration of therapy. The median UPC was $0.21(0.007-$ 8.39) with a median reduction of $0.11(-0.05-6.13)$

Conclusion: Overall, each of the GLP-1 agonists was effective in safely reducing $\mathrm{HgA} 1 \mathrm{c}$ in older patients with type 2 diabetes and Stage 3-4 CKD without significantly impacting eGFR. Further studies are warranted to validate these findings.

\section{Keywords}

Diabetes, Chronic kidney disease, GLP1 inhibitors, Evidence-based medicine, Pharmacology, Pharmacotherapy

\section{Introduction}

Diabetes accounts for $50 \%$ of cases of new onset end stage renal disease (ESRD) making it the leading cause [1]. The rate of diabetic kidney disease (DKD) is approximately 20 per 10,000 patients and has declined by approximately $28.3 \%$ over the last 2 decades [2]. This is attributable to improvements in the early diagnosis and medical management of diabetes.

Tight glycemic control has been demonstrated to reduce the incidence of microvascular complications in type 1 and 2 diabetes (T2D) [3,4]. However, tight control comes at the risk of hypoglycemia. The American Diabetes Association has recommended an individualized HbA1c target of 7-8\% in patients with co-morbidities and increased risk of hypoglycemia [5]. Recently, the ADVANCE-ON study demonstrated tight glycemic control with an average $\mathrm{HbA1c}$ of $7.2 \%$ led to a reduction in the onset of ESRD with more pronounced effects in early DKD [6]. In the setting of DKD, patients are at increased risk of hypoglycemia due to reduced gluconeogenesis in the kidney and altered pharmacokinetics of oral and injectable hypoglycemic agents. The half-life of sulfonylureas and insulin are prolonged in chronic kidney disease (CKD) increasing the risk of hypoglycemia. Additionally, the safety of metformin has not been studied in CKD stage 4-5 and is not recommended in advanced CKD due to the increased risk of lactic acidosis.

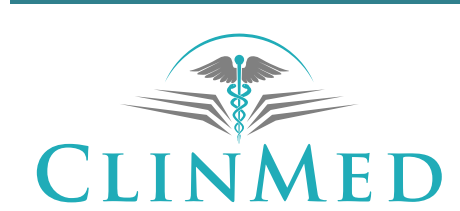

INTERNATIONAL LIBRARY
Citation: Awdishu L, Morello CM (2018) Efficacy and Safety of GLP-1 Agonists in Chronic Kidney Disease: A Case Series. Clin Med Rev Case Rep 5:242. doi.org/10.23937/2378-3656/1410242

Accepted: November 15, 2018: Published: November 17, 2018

Copyright: (c) 2018 Awdishu L, et al. This is an open-access article distributed under the terms of the Creative Commons Attribution License, which permits unrestricted use, distribution, and reproduction in any medium, provided the original author and source are credited. 
Newer therapies such as glucagon-like peptide-1 receptor agonists (GLP-1 RA), dipeptidyl peptidase-4 (DPP-4) inhibitors and sodium-glucose co-transporter-2 (SGLT2) inhibitors represent exciting therapies for managing T2D and slowing the progression of DKD. The majority of studies to date involving these agents have focused on early DKD with average GFR greater than $60 \mathrm{ml} /$ $\min / 1.73$ [7-9].

GLP-1 RAs improve HgA1c by an average of $1 \%$ and have added benefits of increased satiety and weight loss [10]. GLP-1 receptors located in the kidney have effects on control of solute and water excretion. Administration of GLP-1 RA is associated with natriuresis, diuresis, reductions in blood pressure and albuminuria as well as slowing glomerular filtration rate (GFR) decline [10]. GLP-1 RA show considerable promise for improving the outcomes of DKD; however, the safety of these agents has not been studied in advanced CKD stages 3-5. We present a case series of patients with advanced DKD treated with GLP-1 RAs in a comprehensive multidisciplinary CKD clinic. Each patient sees a dietitian, pharmacist, nurse, social worker and physician at every visit. This study was approved by the University of California San Diego Institutional Review Board for the study of human subjects.

\section{Case Series}

\section{Exenatide extended release}

In a 50-year-old obese Hispanic male patient with a past medical history (PMH) of T2D, morbid obesity, coronary artery disease (CAD), chronic non-alcoholic steatohepatitis, proteinuria, and CKD stage $3 a$, exenatide extended release (ER) $2 \mathrm{mg}$ injected once weekly (Bydurion) was initiated three years prior. Initial eGFR, urine protein to creatinine ratio (UPC) and A1C were $47 \mathrm{~mL}$ / min, $8.4 \mathrm{~g} / \mathrm{g}$ and $8.3 \%$, respectively, and the patient was obese with a BMI of $32.2 \mathrm{~kg} / \mathrm{m}^{2}$ and weight of $110.7 \mathrm{~kg}$. By the first year of therapy, he experienced a significant improvement in glycemic control and weight loss with an $\mathrm{A} 1 \mathrm{C}$ of $5.6 \%$ and $\mathrm{BMI}$ of $29 \mathrm{~kg} / \mathrm{m}^{2}$ and he maintained his weight loss by year three and his $\mathrm{A} 1 \mathrm{C}$ continued to decline to $5.3 \%$. His renal function declined over the three year period with a GFR at one and three years of 36 and $29 \mathrm{~mL} / \mathrm{min}$, respectively, with improved UPC of $1.9 \mathrm{~g} / \mathrm{g}$ and $2.3 \mathrm{~g} / \mathrm{g}$, respectively. Overall, this younger T2D and CKD stage 3a patient with mildly complex co-morbidities realized significant glycemic control (> 3\% A1C reduction, and $\mathrm{A} 1 \mathrm{C}<6 \%$ ), weight loss with a reduction in obesity characterization (BMI $<30 \mathrm{~kg} / \mathrm{m}^{2}$ ) and improved UPC with long term exenatide ER use, despite a decline in GFR.

In a 78-year-old obese Caucasian man with a $\mathrm{PMH}$ significant for prostate cancer, major depressive disorder, spinal stenosis, T2D, CKD stage 3, nephrolithiasis, anemia of chronic disease, osteoarthritis (OA), gastro-esophageal reflux disease, obstructive sleep apnea, HTN, hyperlipidemia (HL), and obesity, exenatide ER 2 mg once weekly was initiated three years prior. Baseline renal, glycemia and weight status were GFR $30 \mathrm{~mL}$ / $\mathrm{min}$, UPC $0.09 \mathrm{~g} / \mathrm{g}, \mathrm{A} 1 \mathrm{C} 7.1 \%$ and $\mathrm{BMI} 34.2 \mathrm{~kg} / \mathrm{m}^{2}$ with weight of $103.5 \mathrm{~kg}$. Along with exenatide ER, the patient followed a weight loss diet. After one year of therapy, during which he experienced one acute kidney injury (AKI) event, he realized a reduction in $\mathrm{A} 1 \mathrm{C}(6.9 \%)$ and weight loss (BMI $29.2 \mathrm{~kg} / \mathrm{m}^{2}$ and weight $87.1 \mathrm{~kg}$ ) without loss of renal function (GFR $31 \mathrm{~mL} / \mathrm{min}$ and UPC 0.07 $\mathrm{g} / \mathrm{g})$. At three years following exenatide ER initiation, his A1C continued to decline (6.2\%) and GFR increased to $49 \mathrm{~mL} / \mathrm{min}$ with stable weight at BMI $29.7 \mathrm{~kg} / \mathrm{m}^{2}$. This older patient with a complex medical history experienced moderate glycemic control (A1C reduction $0.9 \%$ and $<7 \% \mathrm{~A} 1 \mathrm{C}$ ) with an improvement in renal status (GFR increased $19 \mathrm{~mL} / \mathrm{min}$ ). Coupled with an improved diet, at one year following exenatide ER initiation he experienced a significant weight reduction (BMI reduction of $5 \mathrm{~kg} / \mathrm{m}^{2}$ ), which he sustained by year three of therapy.

\section{Liraglutide}

Liraglutide was titrated to $1.8 \mathrm{mg}$ once daily injections in a 62-year-old Caucasian female with a $\mathrm{PMH}$ of T2D, CKD stage 3, HTN, HL, hypothyroidism, asth$\mathrm{ma}$, attention deficit hyperactivity disorder and spinal stenosis. Baseline labs were GFR $39 \mathrm{~mL} / \mathrm{min}$, UPC 0.01 $\mathrm{g} / \mathrm{g}, \mathrm{A} 1 \mathrm{C} 8.0 \%$ and BMI $27.8 \mathrm{~kg} / \mathrm{m}^{2}$, and weight $65.8 \mathrm{~kg}$. Following 16 months of therapy, she experienced significant glycemic improvement (A1C reduction to $5.5 \%$ ), with an increased GFR ( $46 \mathrm{~mL} / \mathrm{min}$ with UPC $0.05 \mathrm{~g} / \mathrm{g}$ ) and no change in weight $\left(65.3 \mathrm{~kg}, \mathrm{BMI} 28.1 \mathrm{~kg} / \mathrm{m}^{2}\right)$. This middle aged patient with T2D and CKD stage 3 with a complex PMH notable for mobility, multiple metabolic disorders and mental health issues, realized significant glycemic control $(2.5 \% \mathrm{~A} 1 \mathrm{C}$ reduction, and $\mathrm{A} 1 \mathrm{C}<6 \%$ ) and slight GFR improvement without weight gain.

Similarly, outcomes were demonstrated in a 67-yearold obese Caucasian female who had a lower baseline GFR of $29 \mathrm{~mL} / \mathrm{min}$ when liraglutide was initiated and titrated to $1.8 \mathrm{mg}$ once daily. PMH was significant for T2D, CKD stage 4, HTN, HL, hypothyroidism, subclinical depression, and $\mathrm{OA}$. At baseline $\mathrm{AIC}, \mathrm{BMI}$ and weight were higher $\left(9.1 \%, 36 \mathrm{~kg} / \mathrm{m}^{2}\right.$, and $93.6 \mathrm{~kg}$, respectively). UPC was $0.02 \mathrm{~g} / \mathrm{g}$. By one year, she experienced a significant reduction in AIC (7.3\%) with no change in weight (BMI $36 \mathrm{~kg} / \mathrm{m}^{2}$ and weight $93.7 \mathrm{~kg}$ ) or renal function (GFR $29 \mathrm{~mL} / \mathrm{min}$ and UPC $0.01 \mathrm{~g} / \mathrm{g}$ ). At three years following liraglutide initiation, her AIC continued to decline $(6.9 \%)$, her weight slightly reduced (BMI $35 \mathrm{~kg} / \mathrm{m}^{2}$ and weight $89.7 \mathrm{~kg}$ ) and GFR slightly reduced $(26 \mathrm{~mL} /$ min with UPC $0.01 \mathrm{~g} / \mathrm{g}$ ). Overall this middle-aged patient experienced significant glycemic control (A1C reduction of $2.2 \%$ and $A 1 C<7 \%$ ) without significant changes in renal function or weight, which was sustained over a three-year period.

\section{Dulaglutide}

Dulaglutide was titrated to $1.5 \mathrm{mg}$ once weekly injec- 
tions in a 78-year-old obese Caucasian male patient with a complex $\mathrm{PMH}$ consisting of human immunodeficiency virus, recurrent $A K I s$ due to angiotensin converting enzyme inhibitor (ACEI) use, basal cell carcinoma, prostate cancer, hepatitis, hepatomegaly, diastolic heart failure, HTN, HL, hypothyroidism and T2D with microvascular complications including retinopathy, CKD stage 3 and diabetic peripheral neuropathy. Initial GFR, UPC and A1C were $48 \mathrm{~mL} / \mathrm{min}, 0.2 \mathrm{~g} / \mathrm{g}$ and $10.1 \%$, respectively, and the patient was obese with a BMI of $34.3 \mathrm{~kg} / \mathrm{m}^{2}$ and weight of $108.4 \mathrm{~kg}$. Following 8 months of therapy, his A1C declined to $9.2 \%$ ( $0.9 \%$ reduction) and his weight remained stable at $106.1 \mathrm{~kg}$ with a $\mathrm{BMI}$ of $33.7 \mathrm{~kg} / \mathrm{m}^{2}$. During this time period he continued to experience recurrent AKIs secondary to ACEI use and hypotension, and his GFR decline to 40 yet his UPC of $0.02 \mathrm{~g} / \mathrm{g} \mathrm{im}$ proved. Because clinical glycemic control was not realized ( $A 1 C>9 \%$ ) within a reasonable time period, dulaglutide was discontinued as the drug cost did not justify continued use. Overall, this older patient with complex comorbidities achieved mild $\mathrm{A} 1 \mathrm{C}$ reduction without impacting renal function.

\section{Summary of cases}

The median BMI at initiation of a GLP-1 agonist was $34.3(27.8-36) \mathrm{kg} / \mathrm{m}^{2}$ and the median decrease in BMI over the duration of therapy was $1(-0.32-5.7) \mathrm{kg} / \mathrm{m}^{2}$. The eGFR at initiation of therapy was $46(29-48) \mathrm{mL} /$ $\mathrm{min} / 1.73 \mathrm{~m}^{2}$ and remained relatively stable over the duration of therapy. The median UPC was 0.21 (0.007$8.39) \mathrm{g} / \mathrm{g}$ with a median reduction of $0.11(-0.05-6.13)$ $\mathrm{g} / \mathrm{g}$.

\section{Discussion}

In this case series, we present five patients with diabetes and CKD stages 3-4 who were prescribed a GLP1 RA. Two patients received exenatide, two liraglutide and one received dulaglutide. These patients were older with a significant number of comorbidities. We found that in patients with a baseline $\mathrm{A} 1 \mathrm{C}$ of $8-10 \%$, the initi-

Table 1: Summary of clinical trials evaluating the use of GLP-1 agonists to treat diabetes in patients with CKD.

\begin{tabular}{|c|c|c|c|c|c|c|c|}
\hline Drug/Trial & $\begin{array}{l}\text { Baseline mean } \\
\text { GFR (SD) } \\
\text { mL/min/1.73 m² }\end{array}$ & $\begin{array}{l}\text { Baseline me- } \\
\text { dian UACR } \\
\mathrm{mg} / \mathrm{g}\end{array}$ & $\begin{array}{l}\text { Baseline } \\
\text { mean A1C } \\
\%\end{array}$ & $\begin{array}{l}\text { Composite } \\
\text { Kidney Out- } \\
\text { come }\end{array}$ & GFR Change & UACR Change & $\begin{array}{l}\text { Body } \\
\text { weight } \\
\text { change }\end{array}$ \\
\hline $\begin{array}{l}\text { Liraglutide } \\
\text { LEADER [9] }\end{array}$ & $\begin{array}{l}80 \\
20.7 \% \text { GFR } 30-59 \\
2.4 \% \text { GFR }<30\end{array}$ & $\begin{array}{l}26.3 \% \text { had } \\
\text { macroalbumin- } \\
\text { uria } \\
10.5 \% \text { had mi- } \\
\text { croalbuminuria }\end{array}$ & 8.7 & $22 \%$ reduction & $\begin{array}{l}-7.44 / 36 \\
\text { months }\end{array}$ & $\begin{array}{l}17 \% \text { reduction } \\
26 \% \text { reduction in } \\
\text { new onset macroal- } \\
\text { buminuria }\end{array}$ & $-2.3 \mathrm{~kg}$ \\
\hline $\begin{array}{l}\text { Liraglutide } \\
\text { LIRA-RENAL } \\
\text { [11] }\end{array}$ & $\begin{array}{l}45.4 \pm 0.23 \\
43.6 \% \text { GFR } 30-45 \\
55.7 \% \text { GFR } 45-59\end{array}$ & $55.5 \pm 7.58$ & $8.1 \pm 0.8$ & No composite & $\begin{array}{l}-0.35 / 26 \\
\text { weeks }\end{array}$ & $13 \%$ reduction & $-2.4 \mathrm{~kg}$ \\
\hline $\begin{array}{l}\text { Dulaglutide } \\
\text { Tuttle } 2017 \\
\text { [13] }\end{array}$ & $89.4 \pm 17.1$ & $8.9(4.4-23.9)$ & $\begin{array}{l}7.6-8.5 \\
\text { across } 9 \\
\text { studies }\end{array}$ & No composite & $\begin{array}{l}\text { No significant } \\
\text { change in } \\
\text { GFR }\end{array}$ & $\begin{array}{l}-16.7 \% \text { vs. }-10.0 \% \\
\text { for placebo } \\
-20.0 \% \text { vs. }-12.5 \% \\
\text { for active comparator } \\
-20.0 \% \text { vs. }-9.4 \% \text { for } \\
\text { insulin glargine. }\end{array}$ & $\begin{array}{l}\text { Not re- } \\
\text { ported }\end{array}$ \\
\hline $\begin{array}{l}\text { Dulaglutide } \\
\text { AWARD7 } \\
\text { Abstract ADA } \\
2017[14]\end{array}$ & $38.3 \pm 12.8$ & 200 & 8.6 & $\begin{array}{l}\text { No composite } \\
\text { for kidney } \\
\text { events }\end{array}$ & $\begin{array}{l}-0.4 \text { for } 0.75 \\
\mathrm{mg} \text { dose }-0.1 \\
\text { for } 1.5 \mathrm{mg} \\
\text { dose } \\
-1.9 \text { for insulin } \\
\text { glargine }\end{array}$ & $\begin{array}{l}-26.7 \% \text { for } 0.75 \mathrm{mg} \\
-27.7 \% \text { for } 1.5 \mathrm{mg} \\
-16.4 \% \text { in insulin } \\
\text { glargine }\end{array}$ & $-2.8 \mathrm{~kg}$ \\
\hline $\begin{array}{l}\text { EXSCEL } \\
\text { Exenatide ER } \\
{[15]}\end{array}$ & $\begin{array}{l}29.0 \% \text { GFR }>90 \\
49.7 \% \text { GFR } 60-89 \\
21.2 \% \text { GFR } 30-59 \\
0.1 \% \text { GFR }<30\end{array}$ & Not reported & 8.0 & $\begin{array}{l}\text { No composite } \\
\text { for kidney } \\
\text { events }\end{array}$ & $\begin{array}{l}\text { Percentage } \\
\text { of patients } \\
\text { discontinuing } \\
\text { due to eGFR } \\
<30 \mathrm{~mL} / \\
\mathrm{min} / 1.73 \mathrm{~m}^{2} \\
1.1 \% \text { vs. } \\
1.3 \% \text { placebo } \\
\text { ESRD } 0.7 \\
\text { versus } 0.9 \% \\
\text { in placebo }\end{array}$ & $\begin{array}{l}\text { Microalbuminuria } \\
7.2 \text { versus } 7.5 \% \text { in } \\
\text { placebo } \\
\text { Macroalbuminuria } \\
2.2 \text { versus } 2.8 \% \text { in } \\
\text { placebo }\end{array}$ & $-1.27 \mathrm{~kg}$ \\
\hline
\end{tabular}

GFR: Glomerular Filtration Rate; UACR: Urinary Albumin to Creatinine Ratio; kg: Kilogram; ADA: American Diabetes Association; ER: Extended Release. 
ation of a GLP-1 RA was associated with a reduction in A1C of $0.8-3 \%$. Additionally, patients lost weight during the course of therapy and kidney function remained relatively stable. When assessing individual drug effects, liraglutide therapy resulted in the greatest $A 1 C$ reduction (2.2-2.5\%) while maintaining a stable GFR and BMI in two patients with a baseline GFR ranging from 29$39 \mathrm{~mL} / \mathrm{min} / 1.73 \mathrm{~m}^{2}$. Exenatide ER resulted in an $\mathrm{A} 1 \mathrm{C}$ of $1-3 \%$ with a significant reduction in $\mathrm{BMI} 3-5 \mathrm{~kg} / \mathrm{m}^{2}$. GFR was maintained in one patient but progressed in the second. Dulaglutide resulted in an $\mathrm{A} 1 \mathrm{C}$ reduction of $0.9 \%$, stable weight and improvement in proteinuria but a significant decline in GFR. We evaluated the literature and summarized the effects of GLP-1 agonists on diabetes management in patients with CKD (Table 1 ).

\section{Liraglutide}

Liraglutide has demonstrated positive kidney related outcomes in clinical trials (Table 1). In the LEADER trial, patients with T2D receiving liraglutide had a $22 \%$ reduction $(p=0.003)$ in the composite endpoint of persistent macroalbuminuria, decline in GFR to $<45 \mathrm{~mL} / \mathrm{min} / 1.73$ $\mathrm{m}^{2}$ or doubling of SCr [9]. The decline in GFR was found to be $2.48 \mathrm{~mL} / \mathrm{min} / 1.73 \mathrm{~m}^{2}$ per year over a 3 year period. In the LIRA-RENAL study, GFR was relatively stable over a 26-week period [11]. In comparison to our patients, we found that GFR either increased or declined at the anticipated age related rate. In addition, we found that neither of the two patients developed new onset persistent proteinuria, consistent with the LEADER findings of a $26 \%$ reduction in new onset macroalbuminuria. In the LIRA-RENAL study, proteinuria was reduced by $13 \%$ but new onset proteinuria was not reported [11]. In the SCALE trial of 846 overweight and obese patients with T2D, liraglutide resulted in a reduction of $8.4 \pm 7.3 \mathrm{~kg}$ representing $8 \pm 6.7 \%$ body weight [12]. Similarly, our patients experienced a modest weight loss of $0.8-4.2 \%$.

\section{Exenatide}

The EXSCEL trial was a trial of Bydureon versus placebo in 14,752 patients with T2D examining the impact of treatment on cardiovascular outcomes after 2.4 years of treatment (Table 1). The reduction in A1C and weight was $0.53 \%(95 \% \mathrm{Cl},-0.57$ to $-0.50 ; \mathrm{P}<0.001)$ and 1.27 $\mathrm{kg}(95 \% \mathrm{Cl},-1.4$ to $-1.13 ; \mathrm{P}<0.001)$, respectively. Kidney related outcomes were measured for safety purposes. Twenty one percent of study participants had CKD stage 3 at baseline and no difference was found in the incidence of micro- or macroalbuminuria, ESRD or percentage of patients with eGFR $<30 \mathrm{~mL} / \mathrm{min} / 1.73 \mathrm{~m}^{2}$ [15]. No information has been published on the change in kidney related outcomes over the course of this study.

Smaller studies have documented changes in kidney related outcomes after treatment with exenatide regular release formulation. A retrospective study of propensity-score-matched patients receiving exenatide twice daily versus insulin glargine demonstrated urine albumin to creatinine ratio (UACR) decreased from 104 $\mathrm{mg} / \mathrm{g}$ to $47 \mathrm{mg} / \mathrm{g}$, after 1 year of treatment. Patients in this study had a mean eGFR of $79 \mathrm{~mL} / \mathrm{min} / 1.73 \mathrm{~m}^{2}$ at baseline and $21 \%$ had CKD stage 3 . In this study, eGFR remained stable with the distribution of CKD stage 3 remaining at $21 \%$ and stage 4 increasing from $1 \%$ to $2 \%$ after 1 year [16]. In a study of 31 patients with T2D and microalbuminuria, the use of exenatide versus glimepiride resulted in a reduction in $\mathrm{A} 1 \mathrm{C}$ of $1.3 \%$, BMI of $6 \%$ and UACR of $38 \%(p<0.01)$ after 16 weeks of treatment while UACR remained stable in the patients treated with glimepiride [17]. In a study of patients who were overweight with T2D and CKD stage 2, administration of exenatide resulted in increased sodium excretion, no statistically significant changes in GFR or kidney damage markers (i.e. proteinuria, NGAL or KIM-1) [18]. Overall, exenatide appears to have no net change in GFR and a reduction in proteinuria. In comparison to our patients, exenatide ER similarly resulted in significant reductions in $\mathrm{A} 1 \mathrm{C}$ and $\mathrm{BMI}$, while maintaining GFR in one of the two patients.

\section{Dulaglutide}

Tuttle and colleagues evaluated kidney related outcomes from nine trials of dulaglutide compared to placebo, insulin glargine or an active comparator in 6,005 patients with T2D (Table 1). Overall, the analysis demonstrated no significant difference in eGFR and a reduction in proteinuria. Dulaglutide reduced UACR by $16.7 \%$ versus $10.0 \%$ in placebo, $20.0 \%$ versus $12.5 \%$ for active comparators and $20 \%$ versus $9.4 \%$ for insulin glargine. Fewer patients receiving dulaglutide experienced a $40 \%$ decline in eGFR compared to insulin glargine at any point during a 1-year treatment period $(0.26 \%$ versus $1.25 \% ; P=0.012$ ) [13].

The AWARD-7 trial will provide insight into the impact of dulaglutide on kidney related outcomes in patients with T2D and Stage 3 to 4 CKD. Preliminary data from this study of 576 patients who received dulaglutide $1.5 \mathrm{mg}, 0.75 \mathrm{mg}$ or insulin glargine/lispro was published as an abstract. The majority of the study participants had an eGFR $<45 \mathrm{~mL} / \mathrm{min} / 1.73 \mathrm{~m}^{2}, 30 \%$ had Stage 4 CKD and DKD; $45 \%$ with macroalbuminuria and more than $1 / 3$ with microalbuminuria. Higher doses of dulaglutide treatment reduced albuminuria and had a beneficial effect on eGFR decline when compared to patients receiving insulin glargine and lispro. This effect was more pronounced in patients with macroalbuminuria [14]. We did not appreciate these benefits in our patient receiving dulaglutide who had a mild reduction in $\mathrm{A} 1 \mathrm{C}$ and progression in CKD. However, he did not continue therapy due to cost and experienced recurrent AKI, which was thought to be the cause of his CKD progression.

Albuminuria in CKD is a risk factor for both end stage kidney disease and cardiovascular disease [19]. Therapeutic interventions targeted at reducing albuminuria in patients with type 2 diabetes and CKD are associated 
with a significant reduction in the risk of end stage kidney disease [20]. GLP1 is present on the brush border of kidney proximal tubular cells. Inhibiting GLP1 may alter the degradation of peptides in the lumen influencing proximal tubular cell integrity and function in patients with diabetes [21]. GLP1 agonists offer benefits in reducing proteinuria in T2D but have not been studied in advanced CKD. We found that GLP1 agonists are safe and effective therapies for reducing $\mathrm{A} 1 \mathrm{c}$ with the benefit of modest weight loss in complex patients with advanced CKD.

\section{Conflicting and Competing Interests}

The authors do not have conflicting or competing interest.

\section{Funding Statement}

The authors have no conflicts to disclose.

\section{Acknowledgements}

None.

\section{References}

1. Tuttle KR, Bakris GL, Bilous RW, Chiang JL, de Boer IH, et al. (2014) Diabetic kidney disease: A report from an ADA Consensus Conference. Diabetes Care 37: 2864-2883.

2. Gregg EW, Li Y, Wang J, Rios Burrows N, Ali MK, et al. (2014) Changes in diabetes-related complications in the United States, 1990-2010. N Engl J Med 370: 1514-1523.

3. Nathan DM, Genuth S, Lachin J, Cleary P, Crofford O, et al. (1993) The effect of intensive treatment of diabetes on the development and progression of long-term complications in insulin-dependent diabetes mellitus. $\mathrm{N}$ Engl J Med 329: 977-986.

4. (1998) Intensive blood-glucose control with sulphonylureas or insulin compared with conventional treatment and risk of complications in patients with type 2 diabetes (UKPDS 33). UK Prospective Diabetes Study (UKPDS) Group. Lancet 352: 837-853.

5. American Diabetes A (2018) 6. Glycemic Targets: Standards of medical care in Diabetes-2018. Diabetes Care 41: S55-S64.

6. Wong MG, Perkovic V, Chalmers J, Woodward M, Li Q, et al. (2016) Long-term benefits of intensive glucose control for preventing end-stage kidney disease: ADVANCE-ON. Diabetes Care 39: 694-700.

7. Wanner C, Inzucchi SE, Lachin JM, Fitchett D, von Eynatten M, et al. (2016) Empagliflozin and progression of kidney disease in type 2 diabetes. $\mathrm{N}$ Engl J Med 375: 323-334.

8. Neal B, Perkovic V, Mahaffey KW, de Zeeuw D, Fulcher G, et al. (2017) Canagliflozin and cardiovascular and renal events in type 2 diabetes. N Engl J Med 377: 644-657.
9. Mann JFE, Orsted DD, Brown-Frandsen K, Marso SP, Poulter NR, et al. (2017) Liraglutide and renal outcomes in type 2 diabetes. N Engl J Med 377: 839-848.

10. Muskiet MHA, Tonneijck L, Smits MM, van Baar MJB, Kramer $\mathrm{MHH}$, et al. (2017) GLP-1 and the kidney: From physiology to pharmacology and outcomes in diabetes. Nat Rev Nephrol 13: 605-628.

11. Davies MJ, Bain SC, Atkin SL, Rossing P, Scott D, et al. (2016) Efficacy and safety of liraglutide versus placebo as add-on to glucose-lowering therapy in patients with type 2 diabetes and moderate renal impairment (LIRA-RENAL): A randomized clinical trial. Diabetes Care 39: 222-230.

12. Pi-Sunyer X, Astrup A, Fujioka K, Greenway F, Halpern A, et al. (2015) A randomized, controlled trial of $3.0 \mathrm{mg}$ of liraglutide in weight management. N Engl J Med 373: 11-22.

13. Tuttle KR, McKinney TD, Davidson JA, Anglin G, Harper $\mathrm{KD}$, et al. (2017) Effects of once-weekly dulaglutide on kidney function in patients with type 2 diabetes in phase II and III clinical trials. Diabetes Obes Metab 19: 436-441.

14. Tuttle KRLM, Gross JL, Rayner B, Busch RS, Zimmermann AG, et al. (2018) Dulaglutide vs. Glargine, both combined with lispro, mitigated egfr decline in people with type 2 diabetes and moderate-to-severe chronic kidney disease (AWARD-7). American Diabetes Association 78th Scientific Session, Orlando, Floride.

15. Holman RR, Bethel MA, Mentz RJ, Thompson VP, Lokhnygina $Y$, et al. (2017) Effects of once-weekly exenatide on cardiovascular outcomes in type 2 diabetes. $\mathrm{N}$ Engl $\mathrm{J}$ Med 377: 1228-1239.

16. Pawaskar M, Tuttle KR, Li Q, Best JH, Anderson PW (2014) Observational study of kidney function and albuminuria in patients with type 2 diabetes treated with exenatide BID versus insulin glargine. Ann Pharmacother 48: 571-576.

17. Zhang $\mathrm{H}$, Zhang $\mathrm{X}$, Hu C, Lu W (2012) Exenatide reduces urinary transforming growth factor-beta1 and type IV collagen excretion in patients with type 2 diabetes and microalbuminuria. Kidney Blood Press Res 35: 483-488.

18. Tonneijck L, Smits MM, Muskiet MHA, Hoekstra T, Kramer $\mathrm{MHH}$, et al. (2016) Acute renal effects of the GLP-1 receptor agonist exenatide in overweight type 2 diabetes patients: A randomised, double-blind, placebo-controlled trial. Diabetologia 59: 1412-1421.

19. Levey AS, de Jong PE, Coresh J, El Nahas M, Astor BC, et al. (2011) The definition, classification, and prognosis of chronic kidney disease: A KDIGO Controversies Conference report. Kidney Int 80: 17-28.

20. Abe M, Okada K (2015) DPP-4 Inhibitors in Diabetic Patients with Chronic Kidney Disease and End-Stage Kidney Disease on Dialysis in Clinical Practice. Contrib Nephrol 185: 98-115.

21. Panchapakesan U, Pollock C (2015) The role of dipeptidyl peptidase - 4 inhibitors in diabetic kidney disease. Front Immunol 6: 443. 